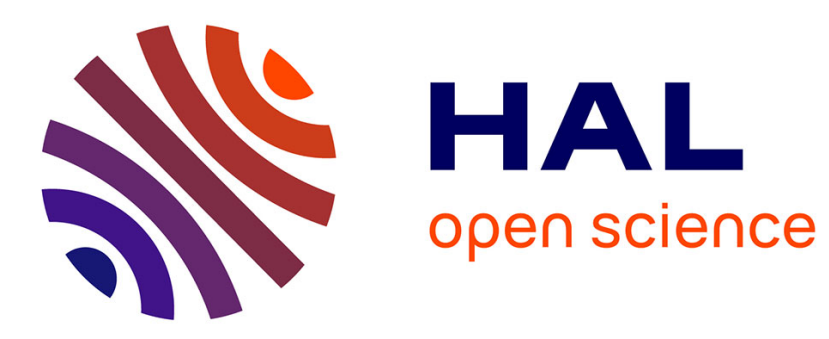

\title{
Research Initiative: Using Games for Better Career Choices
}

\author{
Nick B. Szirbik, Vincent R. Velthuizen
}

\section{To cite this version:}

Nick B. Szirbik, Vincent R. Velthuizen. Research Initiative: Using Games for Better Career Choices. IFIP International Conference on Advances in Production Management Systems (APMS), Sep 2019, Austin, TX, United States. pp.433-439, 10.1007/978-3-030-30000-5_54 . hal-02419204

\section{HAL Id: hal-02419204 \\ https://hal.inria.fr/hal-02419204}

Submitted on 19 Dec 2019

HAL is a multi-disciplinary open access archive for the deposit and dissemination of scientific research documents, whether they are published or not. The documents may come from teaching and research institutions in France or abroad, or from public or private research centers.
L'archive ouverte pluridisciplinaire HAL, est destinée au dépôt et à la diffusion de documents scientifiques de niveau recherche, publiés ou non, émanant des établissements d'enseignement et de recherche français ou étrangers, des laboratoires publics ou privés. 


\title{
Research initiative: Using games for better career choices
}

\author{
Nick B. Szirbik ${ }^{1[0000-0002-3777-446 X]}$ and \\ Vincent R. Velthuizen ${ }^{1[0000-0002-0515-1292]}$ \\ University of Groningen, The Netherlands \\ n.b.szirbik@rug.nl, v.r.velthuizen@rug.nl
}

\begin{abstract}
This paper presents a novel research initiative, that is, to measure the effectiveness of specific game playing in gaining insight into the nature of various career paths in industrial management and industrial engineering. An experiment to measure the effect of a game is proposed and the complexity of the measuring task is discussed. The paper is a position paper, calling for an open discussion of this subject of research.
\end{abstract}

Keywords: Serious gaming · Career choices · Industrial engineering and management.

\section{Introduction}

Through childhood, adolescence, and young adulthood, people constantly set, maintain, and reflect upon their career preferences and goals. In todays dynamic labor market, this process is actually extended into middle-age or even later as many people today change careers late in their working life. From this internal process, coupled with real life constraints and ad hoc decisions, the career path of the individual emerges.

Extant research [4] recognizes the multifaceted difficulties of career defining decisions. Previous research in career development investigated various determinants leading to the choices made by individuals [5. Viewed in a larger societal and systemic perspective, an individual's career path is influenced by and impacts the following stakeholders:

The individual themselves Intrinsic determinants are: the individuals occupational aspirations, self-perceived abilities, affinities and inclinations. Extrinsic determinants are: their perception of the labor market, job prestige and reward levels, and how the individual understands what the job implies.

Family and peers A family may have traditions, expectations, and even demands with respect to the career choices of its members. Peers can exert pressure or be role models.

The education system The choices for education outlets (especially during adolescence and young adulthood) are in interplay with the career choices. Recruitment, marketing, open days in schools, and education fairs can lead to 
influencing both education and career decisions. More recently, the amount of student loans needed for certification is becoming a crucial determinant.

The economy, labor market, and society Politicians and employers have always complained that graduates are not prepared for the actual job market needs at the time of graduation. However, most modern societies have tools to predict and even to plan the job needs of tomorrow, and this information, if disseminated, can be an important career determinant. National surveys about intended career choices can reveal inconsistencies between those intentions and projected needs for the near or more distant future. Governments and employers can offer various incentives to influence career choices in an attempt to resolve such inconsistencies.

This research proposes a closer look at a novel determinant: games, especially games that are designed purposefully to affect career choices. The interplay between games and career path planning constitutes a very large research area and thus needs to be limited. We look at career paths in industrial engineering and management and games that provide insight into what someone with such a background actually does.

Nevertheless, researching games in this context makes it necessary to include additional research subjects into the societal, systemic view outlined above: the game developer, the game organizer. Researchers interested in this field will investigate the interactions between developers and organizers, and also the interactions with the industry, governance, and education system. There is overlap with other fields of research, for example the classic career development studies, and psychology related areas, like career counseling.

\section{Background}

Games, from a commercial perspective, can be largely categorized into ones that are developed for entertainment, and those that are used for other reasons (like training, research, persuasion). The former we call entertainment games and the latter serious games. The focus here is on serious games. For this particular research, the organizers of the game are the stakeholders in the labor market like governments and various industries, which forecast future employment needs and occupational trends.

The interventionist approach to labor market governance is prevalent in economies that have a strategic planning component-a typical example is China, with its 5 year plans, but also other Asian economies like Japan, Taiwan and South Korea. Also the Nordic and Benelux economies in Europe have strategic governance agencie ${ }^{1}$ that want to have leverage in how the labor force of the future is shaped via educational means. For example, in the Netherlands, the Ministry of Education is funding initiatives that use resources (e.g. money, people, expertise) from the higher education to educate $\mathrm{K}-12$ pupils about the reality of careers with many current or projected job openings [9].

\footnotetext{
${ }^{1}$ e.g. in the Netherlands the Social Cultural Planning office
} 
Today's children, adolescents, and young adults are exposed to many kinds of gaming, for example on their phones and on social media. Despite societal criticism, research reveals that gaming in general has a positive influence on the young population [3. Their skills and propensity to understand issues and acquire skills and knowledge via games is recognized in education research as a promising trend.

Many disciplines are using games to supplement their educational tool sets. The authors have been involved in designing and organizing games for pupils in elementary schools (grade six) in the Netherlands that give them a preliminary perspective on jobs in the area of logistics (e.g., inventory manager).

Less researched is whether games can be used to influence career choices. Some anecdotal evidence on this topic has started to emerge, a journalistic source reported an interview from which we take the following quote:

'It was no secret that I hated school. I hated career days, I hated maths, and most of all, I hated having to think about what I wanted to do when I reached adulthood. As a break from all that, I was a kid that spent way too much time on video games.' (Pilot, lawyer, medic: meet the people who turned video game careers into real ones - The Guardian, March $20^{\text {th }} 2019$ [6])

After extensively playing a court game (Phoenix Wright: Ace Attorney), the woman quoted above decided she wanted to become a lawyer. It is also assumed that the younger generation of airplane pilots (both military and commercial, on board and remote) have played lots of flying simulation games before choosing that career and receiving any training. Another example is that creative industries like game development and animation tend to recruit those young people who are the most adept at playing various games.

The Netherlands and other countries in the developed world are confronted with a shortage of labor in the multidisciplinary area of industrial engineering and industrial management. This is due partially to the trend to make people select educational paths and jobs that are focused on a core competency and are very specialized (and thus less multidisciplinary). Another researched reason [10] is that the hybrid type of jobs that include both aspects of engineering and management are less known and understood, because they are not technical enough to appeal to the more technically inclined person, but they are infused by technology related aspects in a way that exceeds the competences of a person inclined to think in a broader, more managerial way.

The position taken in this paper is that governments and employers should apply games to affect career choices and stimulate the creation of games that fit their (projected) needs. When these games exist, schools can use them to give more insight into this kind of jobs. First, research needs to show the efficacy of game based interventions. An experiment for such research is proposed in the next section. If this proves fruitful and games are subsequently implemented on a larger a scale, a longitudinal study should be conducted. 


\section{Proposition for experiments}

The authors have some experience with developing and deploying a game that offers insight into various jobs in logistics for pupils in sixth grade. However, no measurements were taken of these pupils to determine the effect of the game. Playing the game was part of larger project 9](Dutch only), that proposed and experimented with the enlargement of the current curriculum in elementary schools in the Netherlands, specifically for more education about logistics as a discipline and an important industrial sector. Among the goals for this project was to give more insight into logistic jobs, because it was revealed in other surveys that this kind of job is not considered interesting and attractive to pupils of various ages.

\subsection{Instruments to measure changes in pupils}

The aim of this research is to determine if pupils can be enticed to consider career options they otherwise may not have. This allows them to feel competence in a field they were not previously aware of. The feeling of competence within the ability to successfully fulfill a task in a certain job is called occupational selfefficacy and instruments for measuring it are available [8] While some pupils may experience an increase in their occupational self-efficacy it could decrease in others. It is therefore necessary to test the occupational self-efficacy both before and after playing the game. We can then compare changes in individuals, not just within the aggregate of the group.

To design such an experiment and to formulate the questions is still work in progress. It is a difficult task because it necessitates knowledge from both studies in career choices and psychology. Ideally, this research should be done by a multidisciplinary team. Starting points here are the works of Bandura and Schunck [1] and Barak [2, which led to the career interests emergence model of Lent, Brown, and Hackett [5].

\subsection{Game design}

The game mentioned above ${ }^{2}$ will serve as the foundation for this research. In its current form the game allows pupils to manage a store: they are placing and fulfilling orders, keeping stocks, investing in warehousing and/or transportation, etc. The game is aimed at sixth graders (the last year of Dutch primary school) and it is intended to be learned and played individually in a single session. The players can measure their success in several ways: the amount of money the make, their customers' satisfaction or their score which incorporates several such factors. The score is intended as an objective measure of success, though players are encouraged to find their own fun.

We envision several potential extensions of this game. Implementing and researching these will help refine how a game can influence career path determinants. Examples of such extensions are:

\footnotetext{
$\overline{2}$ available in Dutch and English at: http://ontdeklogistiek.nl/game/
} 
- Additional measures, for example: environmental impact, can be added to further diversify "success".

- "Develop/Affect" a buying/selling strategy which can be tweaked but does not require continuous input from the player.

- A multiplayer component, where supply and demand are shared (and competed over) among several players.

- Playing over a longer period (e.g. a week) showing differences between shortand long term strategies.

\section{3 $\quad$ Effects to be measured}

First, we intend to show that games have an impact on a player's perceptions. A very relevant measure for which instruments already exist is occupational self-efficacy. A change there indicates that the player has adjusted their own expected success in that particular field. Our hypothesis is that this effect is (generally) positive for jobs one would like to encourage people to choose, though persuading people not to choose overfull career paths can also be valuable. Selfefficacy alone is not enough however, as research by Lent reveals: 'self-efficacy may not translate into interests unless people expect their activity involvement to be rewarded' [5]. For example, the perception of rewards and prestige of a kind of job have to be taken into account. Whether that should be in the scope of this research remains to be seen.

\section{Discussion and new avenues for research}

The experiment proposed in the previous section is a short-term experiment that measures the job-insight impact of playing the game only once (measuring only occupational self-efficacy). However, if these games are made widely available, data should be collected over a longer time. Periodically, a thorough analysis can be done based on this data, and our understanding of the effectiveness of the game can be incrementally refined. Longer period monitoring of volunteering participants will yield a more complete insight into the inherently long term process of career path development.

Among the many hurdles to pursue this research, the main one is that (further) developing such a game is expensive. It also necessitates a large interdisciplinary effort. Therefore, questions arise: who is paying for the research, development and playing of career path influencing games and which disciplines should be involved? Below, two strategies for approaching the, potential, market are discussed.

First, both industrial and governmental agencies have a strategic stake in future labor markets. They are the obvious avenues for funding the development of such games, by (specialized) commercial partners. These games could even be part of the public image of a company, the way games have been used to cross-promote movies and television shows [7] 
An alternative to such a game development and deployment scheme would be that industry and government invest in academic centers that are specialized in participatory methods for education (as their research focus). Current experience of developing games in such a context shows that using Commercial off-the-shelf (COTS) tools en components for games ${ }^{3}$ lead to results that are comparable in look and feel to the commercial games. A hybrid between the two aforementioned development schemes is also possible. The results of the research presented can serve as a basis for a thorough stakeholder analysis to explore what the current market can support.

More technical issues and questions related to the game development are related to the game architecture. From other serious games, is there an architecture that is appropriate for this task? For example, is it better to have a multiplayer game, which involve cooperation and competition between human players, or individually played games? Should the game be immersive, giving the player the sense of being transported into another world, or should it be firmly grounded in their current reality? These architectural choices have a big impact on how the game is developed, played, and maintained. They also affect what a player can potentially learn from the game, i.e. can the game reflect the social (multiplayer) aspects of a job?

Additionally, from an even more generic architecture perspective, the game based approach is not the only participatory method that could bring this type of insight into the nature of a job. Other research can look into alternative participatory educational activities and tools, for example co-creation during hackathons, which can be either in a real or a simulated environment.

\section{Conclusion}

This paper is mostly a position paper, and its main contribution is to start a discussion on how this research should be conducted and what are promising avenues of exploration. First a novel research initiative is explained, that is to measure the effectiveness of specific game playing in gaining insight into the nature of various career paths in industrial management and industrial engineering. Next, an experiment to measure the influence of a game on a players occupational self-efficacy in a controlled environment is tentatively proposed and the complexity of the research undertaking towards the measuring task is discussed.

More generally, the research could be extended to investigate the comparative impact of participatory methods on career determinants. Interested readers are encouraged to participate in workshops that further discuss this subject of research.

\footnotetext{
${ }^{3}$ e.g., COTS like game engines, real-world simulators, multiplayer game servers
} 


\section{References}

1. Bandura, A., Schunk, D.H.: Cultivating competence, self-efficacy, and intrinsic interest through proximal self-motivation. Journal of Personality and Social Psychology 41(3), 586 (1981)

2. Barak, A.: Vocational interests: A cognitive view. Journal of Vocational Behavior 19(1), 1-14 (1981)

3. Durkin, K., Barber, B.: Not so doomed: computer game play and positive adolescent development. Journal of Applied Developmental Psychology 23(4), 373 - 392 (2002). https://doi.org/10.1016/S0193-3973(02)00124-7, http://www. sciencedirect.com/science/article/pii/S0193397302001247

4. Gati, I., Amir, T., Landman, S.: Career counsellors' perceptions of the severity of career decision-making difficulties. British Journal of Guidance \& Counselling 38(4), 393-408 (2010). https://doi.org/10.1080/03069885.2010.503700. https://doi.org/10.1080/03069885.2010.503700

5. Lent, R.W., Brown, S.D., Hackett, G.: Toward a unifying social cognitive theory of career and academic interest, choice, and performance. Journal of Vocational Behavior 45(1), $79-122$ (1994). https://doi.org/https://doi.org/10.1006/jvbe.1994.1027, http://www.sciencedirect. com/science/article/pii/S000187918471027X

6. Maher, C.: Pilot, lawyer, medic: meet the people who turned video game careers into real ones. The Guardian (March 2019), https://www.theguardian. com/games/2019/mar/20/pilot-lawyer-medic-meet-the-people-who-turnedvideo-game-careers-into-real-ones

7. Picard, M., Fandango, G.: Video games and their relationship with other media. The video game explosion: A history from Pong to Playstation an beyond, Greenwood Press, Westport pp. 293-300 (2008)

8. Rigotti, T., Schyns, B., Mohr, G.: A short version of the occupational self-efficacy scale: Structural and construct validity across five countries. Journal of Career Assessment 16(2), 238-255 (2008). https://doi.org/10.1177/1069072707305763

9. Spronk, C., Alvarez, J.L., Dam, J., Hahn, J., Vermeulen, R., Riezebos, J., Kokx, W., Vis, I.: Lean in het voortgezet onderwijs: een overzicht van eerste projectresultaten. University of Groningen (2016), https://www.rug. nl/cope/docs/reportleanvo.pdf

10. Tremblay, M., Wils, T., Proulx, C.: Determinants of career path preferences among canadian engineers. Journal of Engineering and Technology Management 19(1), 1 - 23 (2002). https://doi.org/10.1016/S0923-4748(01)00043-1, http: //www.sciencedirect.com/science/article/pii/S0923474801000431 